JKM (Jurnal Kebidanan Malahayati),Vol 7,No.4.Oktober 2021,

ISSN (Print) 2476-8944 ISSN (Online) 2579-762X, Hal 711-719

\title{
KEJADIAN INFEKSI SALURAN PERNAPASAN AKUT PADA BAYI
}

\author{
Yenny Aulya ${ }^{1 *}$, Suprihatin ${ }^{2}$, Siti Badriah Ahmad ${ }^{3}$ \\ 1,2,3 Program Studi Kebidanan, Fakultas IImu Kesehatan ,Universitas Nasional \\ Korespondensi *email: yenny.aulya@civitas.unas.ac.id
}

\section{ABSTRACK EVENTS OF ACUTE RESPIRATORY TRACT INFECTIONS IN INFANTS}

Background: Based on WHO (Word Health Organization) report, Acute Respiratory Infection is still a major health problem in the world. This disease is a major cause of infectious disease morbidity and mortality worldwide. $59 \%$ of the visit rates at Zaenab Medika Clinic is Acute Respiratory Infection.

Objective: This study aims to analyze the incidence of Acute Respiratory Infection among infants in Zaenab Medika Clinic district Bekasi.

Methodology: This research is an analytic epidemiological study with a cross-sectional study design. The sample in this study were 88 infants. The sampling technique uses accidental sampling technique. The research instrument consisted of questionnaires, luxmeter, rollmeter, KMS. The questionnaire was tested for validity and reliability with a Cronbach's alpha coefficient of 0.972. Data were analyzed using univariate and bivariate analysis, the Chi-Square test to prove whether there was a relationship between variables.

Results: The results of the bivariate analysis, it was that there was one independent variable related to the incidence of Acute Respiratory Infection in infants at the Zaenab Medika Clinic in Bekasi Regency, namely the physical environment of residence with a $p$ value $=0.027$. While the unrelated variables are maternal education, exclusive breastfeeding, and nutritional status.

Conclusions: There is a Significant relationship between the physical environment of the residence and the incidence of Acute Respiratory Infection in infants.

Suggestion Mothers who have babies with Acute Respiratory Infection are expected to pay more attention to the physical environment of the residence in accordance with the home health requirements of the Republic of Indonesia's Ministry of Health.

Keywords: Physical environment of residence, maternal education, exclusive breastfeeding, nutritional status

\section{ABSTRAK}

Latar Belakang: Berdasarkan laporan WHO (Word Health Organization), Penyakit Infeksi Saluran Pernapasan Akut (ISPA) masih menjadi masalah kesehatan utama di dunia penyakit ini menjadi penyebab utama morbiditas dan mortalitas penyakit infeksi di seluruh dunia. Sebanyak 59\% dari angka kunjungan di Klinik Zaenab Medika adalah penyakit ISPA.

Tujuan: Penelitian ini bertujuan untuk menganalisis kejadian ISPA pada bayi di Klinik Zaenab Medika Kabupaten Bekasi

Metodologi: Penelitian ini merupakan penelitian epidemiologi analitik dengan desain studi cross-sectional. Sampel dalam penelitian ini berjumlah 88 bayi. Teknik pengambilan sampel menggunakan teknik accidental sampling. Instrumen penelitian terdiri dari kuesioner, luxmeter, rollmeter, KMS. Kuesioner telah diuji validitas dan reabilitas dengan nilai koefisien cronbach's alpha 0,972. Data dianalisis menggunkan analisis univariat dan bivariat yaitu uji Chi-Square untuk membuktikan ada tidaknya hubungan antar variabel.

Hasil Penelitian: Hasil analisis bivariat di ketahui bahwa terdapat satu variabel independen yang berhubungan dengan kejadian ISPA pada bayi di Klinik Zaenab Medika Kabupaten Bekasi, yaitu lingkungan fisik tempat tinggal dengan nilai $p=0,027$. Sedangkan variabel yang tidak berhubungan yaitu Pendidikan ibu, ASI ekslusif, dan Status gizi

Kesimpulan: Ada hubungan Signifikan antar Lingkungan fisik tempat tinggal dengan kejadian ISPA pada bayi. Saran Ibu yang memiliki bayi dengan ISPA di harapkan lebih memperhatikan Lingkungan fisik tempat tinggal sesuai dengan persyartan kesehatan rumah kementrian kesehatan republik indonesia.

Kata kunci: Lingkungan fisik tempat tinggal, pendidikan ibu, ASI ekslusif, Status Gizi 


\section{PENDAHULUAN}

Pembangunan kesehatan pada hakekatnya adalah upaya yang dilaksanakan oleh semua komponen Bangsa Indonesia yang bertujuan untuk meningkatkan kesadaran, kemauan, dan kemampuan hidup sehat bagi setiap orang agar terwujud derajat kesehatan masyarakat yang setinggi-tingginya. Pembangunan kesehatan pada periode 2015-2019 adalah Program Indonesia Sehat dengan sasaran meningkatkan derajat kesehatan dan status gizi masyarakat melalui upaya kesehatan dan pemberdayaan masyarakat. Infeksi Saluran Pernapasan Akut (ISPA) merupakan penyebab utama morbiditas dan mortalitas penyakit menular di dunia. Hampir empat juta orang meninggal setiap tahun. Tingkat mortalitas sangat tinggi pada bayi, anak-anak dan orang lanjut usia, terutama di negara dengan pendapatan perkapita rendah dan menengah Depkes RI, (2017).

Penyakit Infeksi Saluran Pernapasan Akut (ISPA) masih menjadi masalah kesehatan utama di dunia. Penyakit ini menjadi penyebab utama morbiditas dan mortalitas penyakit infeksi di seluruh dunia (WHO, 2014) dengan angka kejadian sebesar 18,8 miliar kasus dan jumlah kematian sebesar 4 juta orang setiap tahunya (WHO, 2015) secara global, ISPA menjadi penyebab ke-7 terbesar dari terjadinya kematian terkait lingkungan (WHO, 2016). Selama tahun 2015, jumlah kematian akibat ISPA tertinggi terjadi di wilayah Afrika, yang selanjutnya diikuti oleh Asia Tenggara (WHO, 2016).

Pada penelitian yang dilakukan Akinyemi \& Morakinyo (2018), menyatakan bahwa penelitian yang mereka lakukan dari tahun 2003 sampai dengan 2013 di Nigeria faktor risiko kejadian ISPA adalah kepadatan penduduk, kepadatan hunian, polusi udara dan sanitasi lingkungan yang buruk. Penelitian yang dilakukan Shibata et al (2014) di Indonesia bagian timur menyatakan bahwa faktor risiko terjadinya ISPA adalah rendahnya tingkat pengetahuan ibu tentang cara merawat anak, pemeberian ASI, pajanan asap rokok, kondisi fisik rumah akibat rendahnya tingkat pendapatan keluarga. Menurut Nirmolia et al (2018) di pemukiman kumuh Kota Dibrugarh banyak faktor yang mempengaruhi kejadian gangguan pernapasan pada balita seperti pemberian ASI ekslusif, imunisasi, sosial ekonomi, polusi udara dan tingginya tingkat pencemaran udara.

Salah satu sasaran pokok pembangunan kesehatan yaitu meningkatnya pengendalian penyakit termasuk penyakit ISPA (Infeksi Saluran Pernapasan Akut) (Kemenkes RI, 2015). Angka kematian akibat pneumonia pada balita tahun 2016 sebesar 0,22\% pada tahun 2017 menjadi 0,34\%. Pada tahun 2017, Angka kematian akibat Pneumonia pada kelompok bayi lebih tinggi yaitu sebesar $0,56 \%$ dibandingkan pada kelompok anak umur 1- 4 tahun sebesar 0,23\% (Kemenkes RI, 2017).

Berdasarkan data dan informasi profil kesehatan Indonesia tahun 2017, jumlah kasus pneumonia pada balita berdasarkan kelompok umur di jawa barat pada tahun 2017, pneuminia balita $<1$ Tahun 46.540 balita yang menderita pneumonia, sedangkan pada pneomonia berat $<1$ Tahun 1.822 balita yang menderita pneumonia (Kemenkes RI, 2017).

Berdasarkan rekap laporan program pengendalian ISPA Kabupaten Bekasi tahun 2018 untuk bayi $<1$ tahun dengan jenis kelamin laki-laki ada 10,874 kasus sedangkan untuk bayi berjenis kelamin perempuan ada 10,397 kasus, kasus bayi dengan ISPA untuk puskesmas suka tenang di desa.Sukawangi untuk bayi laki-laki 246 kasus dan bayi perempuan 284 kasus data Dinas Kesehatan Kabupaten Bekasi (Dinkes RI, 2018).

ISPA pada bayi di Klinik Zaenab Medika cukup tinggi terlihat dari laporan setiap bulan penyakit ISPA selalu menjadi urutan penyakit pertama terbanyak laporan yang didapat di bulan Maret sekitar $59 \%$ bayi menderita ISPA. Sedangkan observasi peneliti di klinik lainnya yang bertempat di desa. Sukawangi $5 \%$ sampai $10 \%$. Berdasarkan uraian hasil survei pendahuluan dan masalah tingginya ISPA pada bayi di Klinik Zaenab Medika maka penulis tertarik untuk melakukan penelitian mengenai kejadian Infeksi Saluran Pernapasan Akut pada bayi di Klinik Zaenab Medika Kabupaten Bekasi.

\section{METODE PENELITIAN}

Penelitian ini adalah observasional analitik dengan pendekatan Cross Sectional design tujuan untuk melihat hubungan sebab akibat, yaitu faktor-faktor yang berhubungan dengan kejadian penyakit ISPA pada bayi, rancangan suatu study epidemiologi yang mempelajari hubungan penyakit dan paparan (faktor penelitian) secara serentak dalam waktu yang bersamaan. Teknik pengumpulan data dengan angket/kuesioner, observasi dan wawancara.

Populasi dalam penelitian ini yaitu 100 bayi, seluruh orang tua Bayi 0-12 bulan yang datang berobat ke Klinik Zaenab Medika Kabupaten Bekasi dengan diagnosa ISPA dan Tidak ISPA.

Instrumen penelitiaan ini adalah kuesioner, luxmeter, rollmeter, KMS, dan alat tulis. Cara 


\section{JKM (Jurnal Kebidanan Malahayati),Vol 7,No.4.Oktober 2021, \\ ISSN (Print) 2476-8944 ISSN (Online) 2579-762X, Hal 711-719}

menggunakan luxmeter dalam pengukuran pencahayaan alami rumah yaitu dengan mengukur pada setiap bagian ruangan yang akan diukur melalui lima titik pada ruangan yang diukur dan hasilnya dirata-rata.

Teknik analisis data yang digunakan ada dua, yaitu teknik analisis deskriptif dan teknik analisis statistik. Teknik analisis deskiptif digunakan untuk mengolah data hasil angket/kuesioner, hasil observasi dan hasil wawancara sedangkan teknik analisis statistik digunakan untuk mengolah data hasil angket/kuesioner dan menguji hipotesi penelitian. Teknik analisis statistik yang digunakan dibagi menjadi analisis univariat dan bivariat. Analisis data tersebut akan menggunakan uji ChiSquare dengan taraf signifikansi $a=5 \%(0,05)$.

Penelitian ini dilaksanakan dengan empat tahap yaitu (1) pengumpulan data, (2) tabulasi data, (3) analisis data, dan (4) penarikan kesimpulan dan saran.

Penelitian dilakukan di Klinik Zaenab Medika di Kabupaten Bekasi. Penelitian dimulai sejak Bulan Mei Sampai Juli 2019

\section{HASIL DAN PEMBAHASAN Analisis Deskriptif}

Tabel 1.

Distribusi Frekwensi Kejadian ISPA di Klinik Zaenab Medika

\begin{tabular}{lcc}
\hline \multicolumn{1}{r}{ ISPA } & Frekuensi & Persentase \\
\hline Ispa & 56 & $63,6 \%$ \\
Tidak Ispa & 32 & $36,4 \%$ \\
\hline \multicolumn{1}{r}{ Total } & 88 & $100 \%$ \\
\hline
\end{tabular}

Penelitian ini dilakukan terhadap 88 bayi 0 12 bulan. Hasil penelitian yang didapatkan bayi menderita ISPA 56 bayi $(63,6 \%)$ dan 32 yang tidak ISPA ISPA $(36,4 \%)$ adalah infeksi saluran pernapasan yang dapat berlangsung sampai 14 hari (Depkes, 2004).

ISPA adalah infeksi saluran pernapasan yang sering menyerang anak-anak yang dikarnakan anak-anak memiliki kekebalan tubuh yang belum sempurna sehingga sangat rentan terhadap suatu infeksi terlebih dengan anak yang berusia kurang dari 6 tahun (meadow, 2005). Hasil ini sejalan dengan penelitian yang dilakukan Siti Namira (2013).
Tabel 2.

Distribusi Frekwensi Lingkungan Fisik Tempat Tinggal di Klinik Zaenab Medika

\begin{tabular}{lcc}
\hline Lingkungan Fisik & Frekuensi & Persentase \\
\hline Baik & 33 & 37,5 \\
Tidak Baik & 55 & 62,5 \\
\hline \multicolumn{1}{c}{ Total } & 88 & 100 \\
\hline
\end{tabular}

Hasil dari penelitinan didapatkan Lingkungan fisik tempat tinggal baik $33(37,5 \%)$ sedangkan yang tidak baik $55(62,5 \%)$. Lingkungan yang paling kecil lingkupnya adalah lingkungan rumah lingkungan rumah yang tidak sehat akan mempengaruhi terjadinya ISPA Trisnawati \& Kuswatin ( 2013).

Penelitian ini sejalan penelitian Ema Setianingrum (2016). Lingkungan Fisik tempat tinggal termasuk faktor lingkungan yang bisa mempengaruhi terjadinya penyakit ISPA pada bayi. Hal ini dikarnakan lingkungan fisik tempat tinggal yang tidak baik akan mendukung perkembangannya agents penyebab ISPA maupun penularan ISPA pada bayi.

Tabel 3.

Distribusi Frekwensi Pendidikan Ibu di Klinik Zaenab Medika

\begin{tabular}{lcc}
\hline \multicolumn{1}{c}{ Pendidikan } & Frekuensi & Persentase \\
\hline Rendah & 21 & $23,9 \%$ \\
Tinggi & 67 & $76,1 \%$ \\
\hline \multicolumn{1}{c}{ Total } & 88 & $100 \%$ \\
\hline
\end{tabular}

Hasil penelitian yang didapatkan pendidikan rendah $21(23,9 \%)$ sedangkan pendidikan tinggi 67 $(76,1 \%)$. Peningkatan pengetahuan tidak mutlak diperoleh di pendidikan formal, akan tetapi juga dapat diperoleh pada pendidikan non formal. Pengetahuan seseorang tentang sesuatu objek juga mengandung dua aspek yaitu aspek positif dan negatif. Kedua aspek inilah yang akhirnya akan menentukan sikap seseorang terhadap objek tertentu. Semakin banyak aspek positif dari objek yang diketahui, akan menumbuhkan sikap makin positif terhadap objek tersebut (Notoatmodjo, 2010). Penelitian ini sejalan dengan penelitian Fatimah (2017).

Pengetahuan sangat erat kaitannya dengan pendidikan dimana diharapkan seseorang dengan pendidikan tinggi, maka orang tersebut akan semakin luas pula pengetahuannya. Namun perlu ditekankan bahwa seseorang yang berpendidikan rendah tidak berarti mutlak berpengetahuan rendah pula. 
Tabel 4.

Distribusi Frekwensi Bayi Berdasarkan ASI Ekslusif di Klinik Zaenab Medika

\begin{tabular}{ccc}
\hline ASI Ekslusif & Frekuensi & Persentase \\
\hline Ekslusif & 32 & $36,4 \%$ \\
Tidak Ekslusif & 56 & $63,6 \%$ \\
\hline Total & 88 & $100 \%$ \\
\hline
\end{tabular}

Hasil penelitian didapatkan bayi dengan ASI ekslusif sebanyak 32 bayi $(36,4 \%)$ dan tidak asi ekslusif 56 bayi $(63,6 \%)$. Hasil penelitian sejalan dengan penelitianLilis Fatimah (2017).

Salah satu cara pencegahan ISPA adalah dengan pemberian Air Susu Ibu (ASI) eksklusif yaitu pemberian (ASI) pada bayi baru lahir sampai usia enam bulan. ASI mengandung semua zat gizi dan cairan yang dibutuhkan untuk memenuhi seluruh kebutuhan gizi dan cairan pada enam bulan pertama kehidupan. ASI mengandung zat protektif atau zat kekebalan (Sulistiyoningsih, 2011).
Tabel 5.

Distribusi Frekwensi Bayi Berdasarkan Status Gizi di Klinik Zaenab Medika

\begin{tabular}{ccc}
\hline Status Gizi & Frekuensi & Persentase \\
\hline Gizi baik & 77 & $87,5 \%$ \\
Gizi kurang & 11 & $12,5 \%$ \\
\hline Total & 88 & $100 \%$ \\
\hline
\end{tabular}

Hasil yang didapatkan pada penelitian bayi dengan gizi baik sebanyak 77 bayi $(87 \%)$ dan bayi status gizi kurang sebanyak 11 bay (12,5\%). Status gizi sangat diperlukan oleh anak karena dengan nutrisi yang cukup, pertahanan tubuh anak juga semakin kuat. Status gizi yang buruk dapat mempermudah anak terkena infeksi, ISPA dapat mudah sekali terjadi pada anak yang mengalami gizi kurang dengan gizi kurang anak lebih mudah terkena infeksi (Depkes, 2004).

Hasil penelitian ini tidak sejalan dengan penelitian yang dilakukan oleh Siti Namira (2013). Hal ini mungkin saja dapat disebabkan oleh faktorfaktor lain yang dapat mempengaruhi kejadian ISPA.

\section{Analisis Bivariat}

Tabel 6.

Hubungan Lingkungan Fisik Tempat Tinggal dengan Kejadian ISPA di Klinik Zaenab Medika

\begin{tabular}{|c|c|c|c|c|c|c|c|c|}
\hline \multirow{3}{*}{ Lingkungan fisik } & \multicolumn{4}{|c|}{ ISPA pada Bayi } & \multirow{2}{*}{\multicolumn{2}{|c|}{ Total }} & \multirow{3}{*}{$\begin{array}{c}P \\
\text { value }\end{array}$} & \multirow{3}{*}{ OR } \\
\hline & \multicolumn{2}{|c|}{$\mathrm{Ya}$} & \multicolumn{2}{|c|}{ Tidak } & & & & \\
\hline & $\mathbf{N}$ & $\%$ & $\mathbf{N}$ & $\%$ & $\mathbf{N}$ & $\%$ & & \\
\hline Baik & 13 & $39,4 \%$ & 20 & $60,6 \%$ & 33 & $100 \%$ & & \\
\hline Tidak baik & 35 & $63,3 \%$ & 20 & $36,4 \%$ & 55 & $100 \%$ & 0,021 & 0,371 \\
\hline Total & 48 & $54,4 \%$ & 40 & $45,5 \%$ & 88 & $100 \%$ & & \\
\hline
\end{tabular}

Hasil uji statistik pada Tabel 6 didapatkan Lingkungan fisik tempat tinggal baik $39,4 \%$ dan yang tidak baik $63,3 \%$. Dari hasil uji analisis bivariat dengan menggunakan chi square, menunjukkan ada hubungan signifikan antara lingkungan fisik tempat tinggal dengan kejadian ISPA pada bayi dengan nilai $p=0,027$. Dari hasil analisis OR sebesar 0,371 yang berarti bayi dengan lingkungan fisik tempat tinggal tidak baik beresiko mengalami ISPA 0,371 kali terkena ISPA dibandingan bayi dengan lingkungan fisik tempat tinggal baik.

Penelitian menunjukkan bahwa risiko bayi terkena ISPA akan meningkat jika tinggal di lingkungan fisik tempat tinggal yang tidak baik. Lingkungan fisik tempat tinggal dalam penelitian ini berkaitan dengan ventilasi, pencahayaan, jenis diding, jenis lantai dan atap. Kondisi lingkungan fisik tempat tinggal yang tidak baik disebabkan karena status sosio ekonomi yang rendah, sehingga keluarga hanya mampu membuat rumah dari dinding yang terbuat dari anyaman bambu atau belum seluruhnya terbuat dari bahan yang tidak mudah terbakar. Dinding rumah yang yang terbuat dari anyaman bambu maupun dari kayu umumnya banyak berdebu yang dapat menjadi media bagi virus atau bakteri untuk terhirup penghuni rumah yang terbawa oleh angin.

Kesehatan perumahan dan pemukiman adalah kondisi fisik, kimia, biologi di dalam rumah, lingkungan rumah dan perumahan yang memungkinkan penghuni mendapat derajat kesehatan yang optimal. Persyaratan kesehatan perumahan dan lingkungan pemukiman merupakan ketentuan teknis kesehatan yang wajib dipenuhi dalam rangka melindungi penghuni dan masyarakat 


\section{JKM (Jurnal Kebidanan Malahayati),Vol 7,No.4.Oktober 2021, \\ ISSN (Print) 2476-8944 ISSN (Online) 2579-762X, Hal 711-719}

sekitar dari bahaya atau gangguan kesehatan. Persyaratan kesehatan perumahan yang meliputi persyaratan lingkungan pemukiman serta persyaratan rumah itu sendiri, sangat diperlukan karena pembangunan perumahan berpengaruh sangat besar terhadap peningkatan derajat kesehatan individu, keluarga, dan masyarakat (Keman, S. 2005).

Hal ini sesuai dengan penelitian Adriyani (2017) yang menyatakan bahwa ada hubungan sanitasi fisik rumah dengan kejadian ISPA pada balita di Desa Tumapel Kabupaten Mojokerto.

Menurut peneliti penyuluhan merupakan salah satu cara memberikan pendidikan kesehatan lingkungan fisik tempat tinggal. Penyuluhan sendiri dapat meningkatkan pengetahuan responden. Selain itu penyuluhan dapat dilakukan dimana saja dan kapan saja sehingga memudahkan pembicara. Dalam hal ini responden diberikan informasi melalui penyuluhan.

Tabel 7

Hubungan Pendidikan Ibu dengan Kejadian ISPA pada bayi di Klinik Zaenab Medika

\begin{tabular}{|c|c|c|c|c|c|c|c|c|}
\hline \multirow{3}{*}{ Pendidikan } & \multicolumn{4}{|c|}{ ISPA Pada Bayi } & \multirow{2}{*}{\multicolumn{2}{|c|}{ Total }} & \multirow{3}{*}{$P$ value } & \multirow{3}{*}{ OR } \\
\hline & \multicolumn{2}{|r|}{$\mathrm{Ya}$} & \multicolumn{2}{|c|}{ Tidak } & & & & \\
\hline & $\mathbf{N}$ & $\%$ & $\mathbf{N}$ & $\%$ & $\mathbf{N}$ & $\%$ & & \\
\hline Rendah & 10 & $47,6 \%$ & 11 & $52,4 \%$ & 21 & $100 \%$ & & \\
\hline Tinggi & 38 & $56,7 \%$ & 29 & $43,3 \%$ & 67 & $100 \%$ & 0,465 & 0,694 \\
\hline Total & 48 & $54,5 \%$ & 40 & $45,5 \%$ & 88 & $100 \%$ & & \\
\hline
\end{tabular}

Hasil uji statistik pada Tabel 7 didapat responden berpendidikan rendah yang bayinya menderita ISPA $(47,6 \%)$ sedangkan responden yang berpendidikan tinggi 38 bayi $(56,7 \%)$. Berdasarkan uji chi-square diperoleh nilai $p=0,0465$ sehingga disimpulkan bahwa tidak ada hubungan signifikan antara pendidikan ibu dengan kejadian ISPA pada bayi di Klinik Zaenab Medika. Pada penelitian ini tingkat pendidikan ibu dibagi dalam 2 kategori yakni pendidikan rendah (tidak sekolah, tamat SD, tamat SMP) dan tinggi (SMA, D3, S1).

Pendidikan ikut menentukan atau mempengaruhi mudah tidaknya seseorang menerima pengetahuan, semakin tinggi pendidikan masyarakat maka diharapkan penerimaan pengetahuan akan semakin mudah sehingga diharapkan dapat merubah perilaku seseorang. Berdasarkan pengaruh terhadap kesehatan dan perilaku seseorang peran pendidikan juga berpengaruh terhadap lingkungan, pelayanan kesehatan dan juga heriditas (Achmadi, 2008).

Penelitian ini sejalan dengan penelitian yang dilakukan Fitri (2004) dimana tidak ada hubungan antara pendidikan orang tua dengan kejadian ISPA pada balita. Namun hal ini bertolak belakang dengan penelitian Citra (2012) dan Suptiaptini (2007), menunjukkan adanya hubungan antara pendidikan ibu dengan kejadian ISPA pada balita. Ibu yang berpendidikan rendah mempunyai resiko untuk menderita ISPA lebih besar dibandingkan dengan ibu balita yang berpendidikan tinggi.

Menurut peneliti perananan tenaga kesehatan dalam memberikan pendidikan kesehatan khususnya ISPA dengan tujuan agar ibu yang tidak tahu menjadi tahu bagaimana tandatanda gejala ISPA serta kegiatan pencegahan dan penanggulanganya bagi balita dan anggota keluarga. Pentingnya pendidikan bagi ibu atau anggota keluarga yang lain mengenai gejala penyakit, dan cara penanggulangannya sangat dibutuhkan bagi balita dimana lebih rentan terhadap penyakit. Jika ibu memiliki pengetahuan tinggi, diharapkan balita yang mengalami ISPA atau gejalanya dapat segera di lakukan tindakan penanggulangan.

Tabel 8.

Hubungan ASI Ekslusif dengan Kejadian ISPA pada bayi di Klinik Zaenab Medika

\begin{tabular}{ccccccccc} 
& \multicolumn{4}{c}{ ISPA Bayi } & \multicolumn{2}{c}{ Total } & \multirow{2}{*}{$\boldsymbol{P}$ value } & \multirow{2}{*}{ OR } \\
\cline { 2 - 7 } ASI Ekslusif & \multicolumn{3}{c}{ Ya } & \multicolumn{2}{c}{ Tidak } & & & \\
\cline { 2 - 7 } & $\mathrm{N}$ & $\%$ & $\mathrm{~N}$ & $\%$ & $\mathrm{~N}$ & $\%$ & & \\
\hline Ekslusif & 14 & $43,8 \%$ & 18 & $56,2 \%$ & 32 & $100 \%$ & \multirow{2}{*}{0,124} & \multirow{2}{*}{0,503} \\
Tidak Ekslusif & 34 & $60,7 \%$ & 22 & $39,3 \%$ & 56 & $100 \%$ & & \\
\hline Total & 48 & $54 \%$ & 40 & $45,5 \%$ & 88 & $100 \%$ & & \\
\hline
\end{tabular}


Hasil penelitiaan pada tabel 8 menunjukkan bahwa bayi yang mendapatkan ASI ekslusif dan menederita ISPA $(43,8 \%)$ dan yang tidak mendapatkan ASI eksklusif dan menderita ISPA $(60,7 \%)$. Hasil uji chi square diperoleh nilai $p=$ $0,0,124$ (p-value>0,05) sehingga disimpulkan bahwa tidak ada hubungan signifikan antara ASI ekslusif dengan kejadian ISPA pada bayi di Klinik Zaenab Medika.

ASI merupakan makanan utama bagi bayi yang bersifat alamiah. ASI mengandung berbagai zat gizi yang dibutuhkan dalam proses perkembangan dan pertumbuhan bayi serta mengandung antibodi yang dapat membantu bayi membangun sistem kekebalan tubuh terhadap berbagai macam sumber penyakit. Manfaat yang dapat diberikan dari pemberian ASI eksklusif pada bayi yaitu dapat melindungi bayi dari penyakit diare, infeksi pernapasan, kegemukan, infeksi kandung kemih, infeksi telinga dan lainya (Sinaga, 2012).

Menurut peneliti walaupun pada penelitian ini tidak terdapat hubungan yang bermakna antara pemberian ASI Ekslusif terhadap kejadian ISPA pada bayi di Klinik Zaenab Medika, tetap perlu dilakukan upaya-upaya untuk mengatasi besarnya jumlah balita yang tidak diberikan ASI Ekslusif supaya mencegah berbagai penyakit lain yang mungkin timbul selain ISPA. Upaya-upaya yang dilakukan diantara lain : Sosialisasi perlunya pemberian ASI Ekslusif demi ketahanan tubuh seorang anak terhadap ancaman berbagai macam penyakit. Alternatif bagi ibu yang bekerja agar tetap bisa memberikan ASI Ekslusif. Pengetahuan mengenai fungsi ASI Ekslusif terhadap anak serta melibatkan suami untuk mengingatkan ibu memberikan ASI kepada bayi.

Tabel 9.

Hubungan Status Gizi dengan Kejadian ISPA pada bayi di Klinik Zaenab Medika

\begin{tabular}{lcccccccc}
\hline \multirow{2}{*}{ Status Gizi } & \multicolumn{8}{c}{ ISPA Pada Bayi } \\
\cline { 2 - 7 } & \multicolumn{2}{c}{ Ya } & \multicolumn{2}{c}{ Tidak } & \multicolumn{2}{c}{ Total } & P value & OR \\
\cline { 2 - 7 } & $\mathrm{N}$ & $\%$ & $\mathrm{~N}$ & $\%$ & $\mathrm{~N}$ & $\%$ & & \\
\hline Gizi baik & 41 & $53,2 \%$ & 36 & $46,8 \%$ & 77 & $100 \%$ & 0,571 & \\
Gizi kurang & 7 & $63,6 \%$ & 4 & $36,4 \%$ & 11 & $100 \%$ & & 0,651 \\
\hline \multicolumn{1}{c}{ Total } & 48 & $54,5 \%$ & 40 & $45,5 \%$ & 88 & $100 \%$ & & \\
\hline
\end{tabular}

Pada Tabel 9 didapat bahwa bayi dengan Status gizi baik $(53,2 \%)$ sedangkan bayi dengan Status gizi kurang $(63,6 \%)$. Berdasarkan hasil uji chi square pada penelitian ini disimpulkan bahwa tidak ada hubungan signifikan antara status gizi dengan kejadian ISPA pada bayi dengan nilai $p=0,571$ $(p>0,05)$.

Pada penelitian ini Status gizi balita ditetapkan berdasarkan perbandingan berat badan menurut umur $(B B / U)$ yang mengacu pada keputusan MENKES/SKIXII/2010. Balita dikatakan gizi baik apabila nilai perbandingan antara $\mathrm{BB}$ dan umur yaitu SD 2 dan apabila nilai SD <-2 maka dikatakan status gizi kurang. Menurut Soemirat (2000) kekurangan gizi akan berpengaruh terhadap kekuatan daya tahan tubuh dan respons imunoligis terhadap penyakit dan keracunan.

Penelitian ini sejalan dengan penelitian menurut Muhedir (2002), dan Citra (2012) yang mengatakan bahwa tidak ada hubungan antara status gizi balita dengan kejadian ISPA. Berbeda dengan hasil penelitian yang dilakukan oleh Geturdis (2010) dimana terdapat hubungan antara status gizi balita terhadap kejadian ISPA dimana balita yang gizi kurang beresiko 2,5 kali lebih besar mengalami ISPA karena daya tahan tubuh lemah terhadap serangan virus. Pada penelitian ini Status gizi balita ditetapkan berdasarkan perbandingan berat badan menurut umur (BB/U) yang mengacu pada keputusan MENKES/SK/XI/2010. Balita dikatakan gizi baik apabila nilai perbandingan antara BB dan umur yaitu SD 2 dan apabila nilai SD $<-2$ maka dikatakan status gizi kurang. Menurut Soemirat (2000) kekurangan gizi akan berpengaruh terhadap kekuatan daya tahan tubuh dan respons imunoligis terhadap penyakit dan keracunan.

Dari 88 balita pada penelitian ini ternyata hanya $(63,6)$ bayi yang mempunyai gizi kurang. Walaupun persentase kecil, tetap perlu di lakukan upaya-upaya perbaikan status gizi balita karena perbaikan gizi masyarakat harus dimulai dari perbaikan gizi pada masa bayi dan balita (Notoatmodjo, 2007) seperti : dari instansi kesehatan mengenai makanan-makanan yang mengandung gizi baik dengan harga yang tidak terlalu mahal tapi mempunyai nilau asupan gizi yang tinggi sehingga tidak memberatkan ibu balita. Pemberitahuan akibat-akibat yang akan disebabkan jika balita tidak mempunyai status gizi yang baik sehingga diharapkan menimbulkan rasa takut dan 


\section{JKM (Jurnal Kebidanan Malahayati),Vol 7,No.4.Oktober 2021, \\ ISSN (Print) 2476-8944 ISSN (Online) 2579-762X, Hal 711-719}

kesadaran akan pentingnya makanan yang sehat. Selain makanan, anak-anak perlu diberikan suplemen atau vitamin untuk melengkapi kebutuhan gizi yang kurang.

\section{SIMPULAN}

Ada hubungan Signifikan antara lingkungan fisik tempat tinggal dengan kejadian ISPA pada bayi di Klinik Zaenab Medika.

\section{SARAN}

Masyarakat diharapkan selalu memperhatikan dan berusaha agar Lingkungan fisik tempat tinggal memenuhi syarat kesehatan, salah satunya kepemilikan ventilasi kamar $(>10 \%$ luas lantai), pencahayaan, jendela harus dibuka setiap hari (terutama pagi hari).

\section{DAFTAR PUSTAKA}

Arikunto, S., 2006. Prosedur Penelitian Suatu Pendekatan Praktik. Jakarta: Rineka Cipta. 2010. Prosedur Penelitian Suatu Pendekatan Praktik. Jakarta: Rineka Cipta.

Ardianasari, E., 2016. Buku Pintar Mencegah dan Mengobati Penyakit Bayi \& Anak. Jakarta: Bestari. diakses 20 Juli 2019.

Akinyemi, J. O., \& Morakinyo, O. M., 2018. Household environment and symptoms of childhood acute respiratory tract infections in Nigeria, 2003-2013: a decade of progress and stagnation. BMC Infectious Diseases, 18(1), 1-12. https://doi.org/10.1186/s12879018-3207-5, diakses 28 Mei 2019.

Assegaf. F, Petrus. R, Marni., 2012. Analisis Faktor Resiko Kejadian ISPA DitinjauDari Status Rumah Di Wilayah Kerja Puskesmas Kota Wilayah Utara Kota Kediri.Jurnal IKESMA Volume 11 Nomor 1 September 2015,167-168.

Achmadi, U.F., 2008. Manajemen Penyakit Berbasis Wilayah. Universitas Indonesia Pres. Jakarta.

Benih, C., 2008. Penanggulangan dan Pengobatan ISPA.

http://www.benih.net/lifestyle/gayahidup/ispai nfeksisaluranpernapasanakutpenanggulangan-dan-pengobatannya.html, diakses 25 Maret 2019.

Citra, P., 2012. Hubungan Lingkungan Dalam Rumah Dengan Kejadian ISPA Pada Balita Di Wilayah Kerja Puskesmas Atang Jungket Kecamatan Bies Kabupaten Aceh Tengah Tahun 2012. Skripsi,FKM UI, Depok.

Direktorat Jendral Pengendalian Penyakit dan Penyehatan Lingkungan (Ditjen P2PL).
2012. Pedoman Pengendalian Infeksi Saluran Pernapasan akut. Jakarta: Kementrian Kesehatan Republik Indonesia, Direktorat Jendral Pengendalian Penyakit dan Penyehatan Lingkungan.

Dinata, A., 2007. Aspek Teknis dalam Penyehatan Rumah. http://miqrasehat.blogspot.com/2007/07/aspe k-teknis-dalam-penyehat-rumah.html, diakses 28 Maret 2019.

Depkes R.I., 2002. Penyakit ISPA, Departemen Kesehatan Republik Indonesia, Jakarta.

Depkes. Rl., $2004 . \quad$ Pedoman pemberantasanpenyakit infeksi saluran pernafasan akut untuk penanggulangan pneumonia pada balita. http://repository.uinjkt.ac.id/dspace/bitstream /123456789/24284/1/RAHMAYATUL\%2OFIL LACANO-fkik.pdf. diakses 29 Juli 2019.

Depkes R.I., 2011. Pedoman Pengendalian Infeksi Saluran Pernafasan Akut. Direktorat Jenderal Pengendalian Penyakit dan Penyehatan Lingkungan, Kementrian Kesehatan Republik Indonesia. Jakarta. diakses 10 Juli 2019.

Depkes R.I., 2017. profil kesehatan indonesia. http://www.depkes.go.id/resources/download /pusdatin/profil-kesehatan-indonesia/ProfilKesehatan-Indonesia-tahun-2017.pdf, diakses 1 Mei 2019.

Dinkes R.I., 2018. Program pengendalian ISPA. Dinas Kesehatan Republik Indonesia, Bekasi.

Gunarni, A., Vincentius, S., Mujiono. 2012. "Study Tentang Sanitasi Rumah dan Kejadian ISPA pada Balita di Desa Gemarang Kecamatan Kedunggalar Kabupaten Ngawi". E-ISSN: 2443-0218 Volume 3 Nomer 2.

Gertrudis T, 2010, Hubungan Antara Kadar Partikulat (PM10) Udara Rumah Tinggal Dengan Kejadian ISPA Pada Balita Di Sekitar Pabrik Semen PT Indocement,Citeurep,tahun 2010, Tesis,Fakultas Kesehatan Masyarakat UI, Depok.

Harsono. R., H Rahmawat D., 2016. Gangguan Pernafasan Pada Anak: ISPA, Nuha Medika: Yogyakarta, 2-5.

Hidayat, A.Z. 2008. Pengantar Ilmu Keperawatan Anak I. Jakarta: Salemba medika. http://repository.uinjkt.ac.id/dspace/bitsream/ 123456789/25671/1/SITI\%20NAMIRA\%20fki k.pdf. diakses 21 Juli 2019. 
Iskandar, 2008. Metodologi Penelitian Pendidikan dan Sosial (Kuantitatif dan Kualitatif). Jakarta: Gaung Persada Press.

Kemenkes R.I., 2002. Keputusan Mentri Kesehatan RI Nomor 1537 ./A/Menkes/SKXII/2002 tentang Pedoman Pemberantasan Penyakit Infeksi Saluran Pernafasn Akut untuk Penanggulangan Pneumonia Pada Balita. Kementrian Kesehatan RI. Jakarta.

Kemenkes R.I., 2011. Peraturan menteri kesehatan Republik Indonesia no. 1077/MENKES/PER/V/2011 tentang pedoman penyehatan udara dalam ruang rumah. Kementerian Kesehatan RI. Jakarta.

Kemenkes R.I., 2012. Modul Tatalaksana Standar Pneumonia. Kementrian Kesehatan Republik Indonesia. Jakarta.

Kemenkes R.I., 2013. Badan Penelitian dan Pengembangan Kesehatan, Kementrian Kesehatan Republik Indoneesia. Jakarta.

Kemenkes R.I., 2017. Data dan Informasi profil kesehatan indonesia http://www.pusdatin.kemkes.go.id/resources/ download/pusdatin/profil-kesehatanindonesia/Data-dan-Informasi_ProfilKesehatan-Indonesia-2017.pdf, diakses 1 Mei 2019.

Kristiyansari, W. 2009. ASI Menyusui \& Sadari. Nuha Medika. Yogyakarta. diakses Juli 2019.

Khrisna, A. 2013. Mengenali Keluhan Anda.Jakarta: Informasi Medika. diakses Juli 2019.

Keman, S., 2005. Kesehatan perumahan dan lingkungan pemukiman. Kesehatan Lingkungan Fakultas Kesehatan Masyarakat Universitas Airlangga. Surabaya.

Lembaga Penyelidikan Ekonomi dan Masyarakat Fakultas Ekonomi Universitas Indonesia (LPEM FEUI). 2010. Indonesia Macroeconomic Outlook 2010. Jakarta: Grasido. diakses 24 Mei 2019.

Leli, F., 2017. Faktor-Faktor Yang Berhubungan Dengan Kejadian Infeksi Saluran Pernapasan Akut (ISPA) Pada Bayi Di Wilayah Kerja Puskesmas Kampung Baru Kecamatan Medan Maimun. Skripsi. Program Study Kesehatan Masyarakat Universitas Sumatra Utara, Medan.

Mairuhu, V., Birawida, A. B., \& Manyullei, S. 2008. Faktor yang Berhubungan dengan Kejadian ISPA Pada Balita di Pulau Barrang Lompo Kecamatan Ujung Tanah Subdistrc Makassar City. Hasanudian University Repository, Bagian Kesehatan Lingkungan Fakultas Kesehatan Masyarakat Universitas Hasanudin: 1-8.
Maryunani, A., 2010. IImu Kesehatan Anak Dalam Kebidanan. Jakarta: Trans Info Media. diakses 14 Juli 2019.

Maulidiyah, D.A.P., Retno, A. 2017. Hubungan Usia Balita Dan Sanitasi Fisik Rumah Dengan Kejadian ISPA Di Desa Tumapel Kabupaten Mojokerto, 95-106.

Muhedir 2002. Hubungan faktor-faktor lingkungan rumah dengan kejadian penyakit ISPA pada Anak balita di Kecamatan Jambi Selatan tahun 2002, Tesis, FKM UI, Depok.

Nurhidayah, I., 2007. Hubungan antara Karakteristik Lingkungan Rumah dengan Kejadian Tuberkulosis (TB) pada Anak di Kecamatan Paseh Kabupaten Sumedang. Skripsi. Bandung: Universitas Padjadjaran Fakultas IImu

Notoatmodjo, S., 2005. Metodologi Penelitian Kesehatan. PT.Rineka Cipta. 2010. Metodologi Penelitian Kesehatan. Jakarta: Asdi Mahasatya. 2010. IImu Kesehatan Masyarakat. Jakarta. Rineka Cipta.

Notoatmodjo, S., 2010. Metodologi Penelitian Kesehatan.Jakarta:PT.Rineka Cipta. http://repository.uinjkt.ac.id/dspace/bitstream /123456789/24284/1/RAHMAYATUL\%20FIL LACANO-fkik.pdf. diakses Juli 2019.

Oktaviani, D.F., Purba IG. 2010. Hubungan Kondisi Fisik Rumah dan Perilaku Kelurga Terhadap Kejadian ISPA Pada Anak Balita di Kelurahan Cambai Kota Prambulih Tahun 2010. Jurnal Pembangunan Manusia. 4(12).

Pujiastuti, P., Soemirat, J. And Dirgawati, M. 2013.Karakteristik Anorganik PM10 Di Udara Ambien Terhadap Mortalitas dan Morbiditas Pada Kawasan Industri di Kota Bandung, Reka Lingkungan, 1 (1), pp. 1-11.

Pore, P.D., Ghattargi, Chandrashekhar H., \& Rayate, Madhavi V. 2010. Study of Risk Factors of Acute Respiratory Infection (ARI) in Underfives in Solapur. National Journal of Community Medicine, 1 (2): 63-66.

Supriaptini. 2007. Faktor-Faktor pencemaran udara dalam rumah yang berhubungan dengan kejadian ispa pada balita di indonesia.Jurnal ekologi kesehatan,vol.9.

Soemirat, SJ. 2000. Mortality and Morbidity as Related to Air Polution. A Paper. University of Minnesota.

Sinaga, Kristina, E.R. 2012. Kualitas Lingkungan Fisik Rumah dengan Kejadian ISPA pada Balita di Wilayah Kerja Puskesmas Kelurahan Warakas Kecamatan Tanjung Priok Jakarta Utara 2011, Skripsi, FKM UI,Depok. 


\section{JKM (Jurnal Kebidanan Malahayati),Vol 7,No.4.Oktober 2021, \\ ISSN (Print) 2476-8944 ISSN (Online) 2579-762X, Hal 711-719}

Sulistiyoningsih, H. 2011. Gizi untuk Kesehatan Ibu dan Anak. Graha IImu. Yogyakarta. diakses Juli 2019.

Shibata, T., Wilson, J. L., Watson, L. M., LeDuc, A., Meng, C., La Ane, R., ... \& Maidin, A. 2014. Childhood acute respiratory infections and household environment in an eastern indonesian urban setting. International Journal of Environmental Research and Public Health, 11(12), 1219012203.https://doi.org/10.3390/ijerph1112121 90, diakses 28 Mei 2019.

Sekaran, U. 2014. Research Methods For Business (Edisi 4). Jakarta: Salemba Empat.

Suryanto, 2003. Hubungan Sanitasi Rumah dan Faktor Intern Anak Balita dengan Kejadian ISPA pada Anak Balita. Skripsi. Surabaya: Fakultas Kesehatan Masyarakat Universitas Airlangga.

Sugiyono, 2017. Metode Penelitian Kombinasi (Mixed Methods). Bandung: Alfabeta. Hal. 63-68.https://www.asikbelajar.com/variabelpenelitian-menurut-sugiyono, diakses 28 Maret 2019.

Sutomo, B., \& Anggraini, D.Y. 2010. Menu Sehat Alami Untuk Batita \& Balita. Jakarta: Demedia.

Sunyataningkamto, Z., I., RT A., I, B., Surjono, A., Wibowo, T., Lestari, E. D. and Wastoro, D. 2004 'The Role of Indoor Air Pollution and Other Factors in The Incidence of Pneumonia in Under-Five Childer', Paediatrica Indonesiana, 44 (1), pp.25-29.

Tesepu, R. 2016. Epidemiologi Lingkunga: teori dan aplikasi, Edited by U. Rahmawatu and N. Syamsiah, Jakarta: Bumi Medika, diakses 30 Mei 2019.

Trisnawati, Y., Kuswati K. 2013. "Analisis Faktor Intrinsik dan Ekstrinsik yang Berpengaruh Terhadap Infeksi Saluran Pernapasan Akut (ISPA) pada Balita Tahun 2013". Jurnal Kebidanan Vol.V No.01.
World Health Organization (WHO) 2007. Pencegahan dan Pengendalian Infeksi Saluran Pernafasan Akut (ISPA) yang Cenderung menjadi Epidemi dan Pandemi di Fasilitas Pelayanan Kesehatan, Pedoman Internal WHO, Available at:http://apps.who.int.iris/bitstream/10665/69 707//14/WHO_CDS_EPR_2007.6_ind.pdf, diakses 26 Maret 2019.

World Health Organization (WHO) 2012. Pedoman Teknis Penanggulangan Krisis Kesehatan Akibat Bencana. Jakarta: Bakti Husada.http://repository.uinjkt.ac.id/dspace/b itstream/123456789/25671/1/SITI\%20NAMI RA\%20fkik.pdf. diakses 21 Juli 2019.

World Health Organization (WHO) 2014. Infection Prevention and Control of Epidemic-and Pendemic-prone Acute Respiratory Infection in Health Care, WHO Inatitutional Repository, 1-156.

World Health Organization (WHO) 2015. Protocol For The Investigation of Acute Respiratory IIIness Outbreaks of Unknown Etiology. Brazzaville: Integrated Disease Surveillance Programme Health Security and Emergencies Cluster, Word Health Organization Regional Officer for Africa.

World Health Organization (WHO) 2016. Children: Reducing Mortality, Media center: fact sheet. http://www.who.int/mediacentre//factsheets/f sl178/en/, diakses pada 1 Mei 2019.

World Health Organization (WHO) 2016. Map and Spatial Information Technologies (Geographical Information Systems) in Health and Environment Decision-Making. Scientific data and assesment tools, The Health and Environment Linkages Initiative (HELI). http://www.who.int/heli/tools/maps/en/, diakses pada 1 Mei 2019. 